\title{
Analysis of Job Motivation for Secondary School Teachers of Private and Public Schools in (Punjab) Pakistan
}

\author{
Hassan Danial Aslam \\ Lecturer, Faculty of Management Sciences, The Islamia University of Bahawalpur (Pakistan) \\ Email: hassan.danial@hrmars.com \\ (Corresponding Author)
}

Doi:10.5296/jsr.v4i2.6250

URL: http://dx.doi.org/10.5296/jsr.v4i2.6250

\begin{abstract}
The aim of this research is to explore various issues of motivation for the secondary school teachers of private and public schools. The study also discovers the implementation plans that can be used in order to have highly motivated teachers. In this research qualitative and quantitative methods have been used by the researchers where survey has been conducted in public and private schools. Likert scale is used in quantitative method. Primary data has been collected through questionnaire and interviews. Data was analysed by using t-test in SPSS software. The major findings which researchers found in conducting the research are; Salary is not given to them according to their qualification and workload they have to bear in schools and they seldom enjoy the benefits and monitory packages, Enough resources are not provided to them to work properly, There are alot of students in the class rooms due to which teachers are unable to handle the class and to produce quality work, They are not treated well due to personal biasness and attitude of management, Development programs are not satisfactory. They don't find it beneficial for their career development.
\end{abstract}

\section{Introduction}

Most of us have seen people who do their jobs by doing as little as possible. On their jobs they often come late and leave early. They miss deadlines. They exert minimum effort to complete a task. They usually spend their extra time in the break room and complaining about their jobs. We also know people who give 110 percent to any task given them. They do their work on time and are hardworking. When they are given new projects they approach it with a smile instead of a complaint. What is the reason that these two types of workers are so different? The answer is Motivation.

A motivated person work better and work hard his motivation on the right path leads him to the success. The term motivation is derived from the Latin word movere meaning to move 
(Kretiner, 1998). Motivation is the positive change in mental and physical activities that are targeted towards achievement. (Mitchell, 1982). As Shameena Silva (2009) asserts that motivation could be defined as the activity heavy force within persons that push them to move forward and to perform, in respect to attain their projected wants and opportunity. In simple, it is number of causes that ultimately pull an individual to do a specific task inducing that they possibly will complete their needs and expectations, formerly the job is done As stated by Brown (1994). Motivation is a expression that is used to describe the victory or the breakdown of any difficult task. As Robbins and Judge (2007) define motivation as, "the procedure that report for an individual's strength, route, and determination of attempt in the direction of attaining a goal." As Robins et al (n.d ) asserts that the practice through which a human being efforts are eager going to and continued toward attaining a goal. However the value of effort must also be kept in mind. So the motivation is simply doing the work with efficacy in support of organization. As Remez Sasson (n.d ) asserts the same point that motivation is the inside authority or force that pushes toward acting, do actions and complete. Motivation has most of the things related with the wants and to a much to attain goals, and if they are missing, motivation is lacking too. He additional clarify that some time people want to attain a positive goal but sense something missing, the first push to take first step towards action. Motivation gives direction, guts and energy. It becomes strong when you have the clear image of your visions then it allows you to take initiative step to towards your goals. The level of motivation varies between different individuals in relation to their surrondings. It is to inspire people to do their work in order to increase productivity or profitibility in the workplace. Motivated behavior is usually goal oriented; the goal may be associated with a drive such as hunger or thirst called primary motivation (cited in Dorman and Gaudiano, n.d) Motivation refers to "the reasons underlying behavior" Guay et al., (2010, p. 712) Cited in Lai (April 2011) so the author explained in this phrase motivation related with behavior. Simple acts such as eating are motivated by hunger. E.g. we feel hungry we want to eat something this will be motivation. Desire of education also increases by motivation. Simple acts such as eating are motivated by hunger. E.g. we feel hungry we want to eat something this will be motivation. Desire of education also increases by motivation.

It is mention here that a high percentage of pre-university students appear in International Baccalaureate American High School Diploma and British GCSE/GCE examinations. Many open and distance learning foundations are operative is Pakistan. The national education policies make great effort to, amongst others, safeguard Pakistan ideology; instruct national unity and increase literacy. Even though, there is an elaborate guiding principle defined in Pakistan, subsequent Governments have failed to achieve the desired goals, for example, literacy rate in Pakistan is still 49.9\% (very low for a country of population of 180 million). On the bright side, recent achievements include high ISI for research journals; breaking into top 500 universities of the world and most. Motivation and other related issues in school system: according to the requirement of students, are never encouraged in our country. Education is the key towards success for every country. It helps to boost the economy and beneficial for the society. If we look towards our Education there are many other reasons behind the de-motivation and poor academic performance of students. The interest in 
students to achieve quality education is de-motivated in the recent years. The only thing student require, is Certificate/Degree with passing marks.

\section{Literature Review}

Motivation is a phenomenon through motivation we can do difficult tasks as (cherry, n. d) explained that motivation is defined as the process that creates courage and guides to maintain behavior of goal oriented. Motivation is like that show the reaction in the result in thirst consuming a glass of water to reduce thirst, or reading a book to get knowledge. Motivation has different behavior like emotional, social, and etc. In daily usage, the term motivation is mostly used to explain why a person does something.

The word motivation is derived from the word motivate the word motivation means to move, to satisfy a need or want and to complete any task. Any act, idea or object the individual to act or move to do what needs to be completed is motivation. Motivation may be defined as a willingness to do effort to achieve a goal or task and getting rewards in return. Internal forces that affect a person's alones choice of behavior; Direction: is directed by goals means you have vertical scale to go ahead. Intensity: is the amount of effort allocated, assert that you do effort and hard work for anything. (Al jishi, 2009, p.6)

Motivation is a very common concept and is considered very important to starting an action, and is a concept that widely used in a many of situations. According to Koiso (2003, p.96), "Motivation is considered to be one of the main important factors of success in developing a second or foreign language" Everybody need to have motivated and need reason for actions. Foreign language learners should have the opportunity to be motivated and to complete their basic learning (Qashoa, 2006). "Attitude and motivation are key factors in second language acquisition." (Nagano, 1995, p.72) "Without motivation, success will be very difficult, and the case of learning a second or foreign language is different" (Ushioda, n.d. p.19)

Motivation also define as decision making process through any one can get desired results and can set behavior which will be suitable Buchanan(ending no date) the author also defined the motivation as learned more about human behavior they work on specific goals which have valued to them.

Motivation in an internal state which energies us to achieve something and to complete a task. Motivation can be of many types' achievement motivation, competency motivation, and power motivation. Motivated behavior is usually goal oriented. The goal may be associated with a drive such as hunger or thirst (called primary motivation) (cited in Dorman and Gaudiano ending no date).

Motivation refers to "the reasons underlying behavior" (Guay et al., (2010, p. 712) Cited in Lai (April 2011) so the author explained in this phrase motivation related with behavior. Simple acts such as eating are motivated by hunger. E.g. we feel hungry we want to eat 
something this will be motivation. Desire of education also increases by motivation. Simple acts such as eating are motivated by hunger. E.g. we feel hungry we want to eat something this will be motivation. Desire of education also increases by motivation.

There are many factors to motivate the employees in the organization and in corporation; for each of the four main points that employees need to fulfill, companies have a primary organizational lever to use. This table matches each drive with its corresponding lever and lists specific actions your company can take to make the most of the tools at its disposal.

Motivation have very important role on employee's behavior and have different affects on performance of employees. Through positive motivation employees can be motivated and give good performance and through negative behavior of organization they can be de motivated.

To maintain and to improve employee's effectiveness, it is very important for organization to know their employees and how to improve or maintain their job to satisfy them. Employee performance is very important function of motivation. Managers should do their best to increase employee motivation encourage them through words and that their supervisor should always understand what employees want and fulfill their needs and understand their problems and feelings.

In addition to it, leaders need to motivate employees and trained them to satisfy customers through their behavior or skills, they should resolve managerial or customer related problems, and use their own interest in the organization. It is not just to performing the task gently but actually they should be motivated to care about the organization and its impression. Managers should also have a clear understanding of how motivate the employees to increase the productivity and increase their skills, performance. Managers should invest more then time to know their employees and develop motivational and psychological techniques to improve the effectiveness of employees. Highly motivated employees do better work then others especially if they personally energized they do their best. They will do best to achieve the organizational goals. (Management assistant programe, 2008).

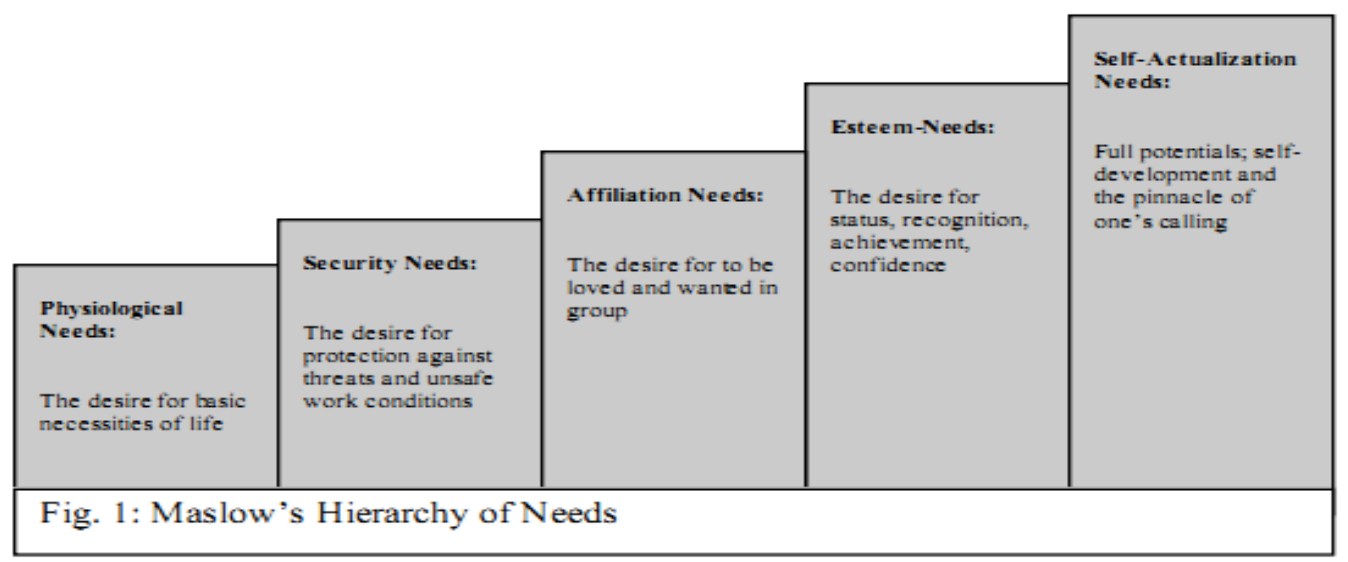


Maslow (1970) has its need based theory of motivation. According to theory a person has five needs physiological needs, security needs, affiliation needs, esteem needs and self actualization needs. Which are discussed in the above conceptual framework. The teachers have all these needs and when these needs are fulfilled he will be motivated automatically.

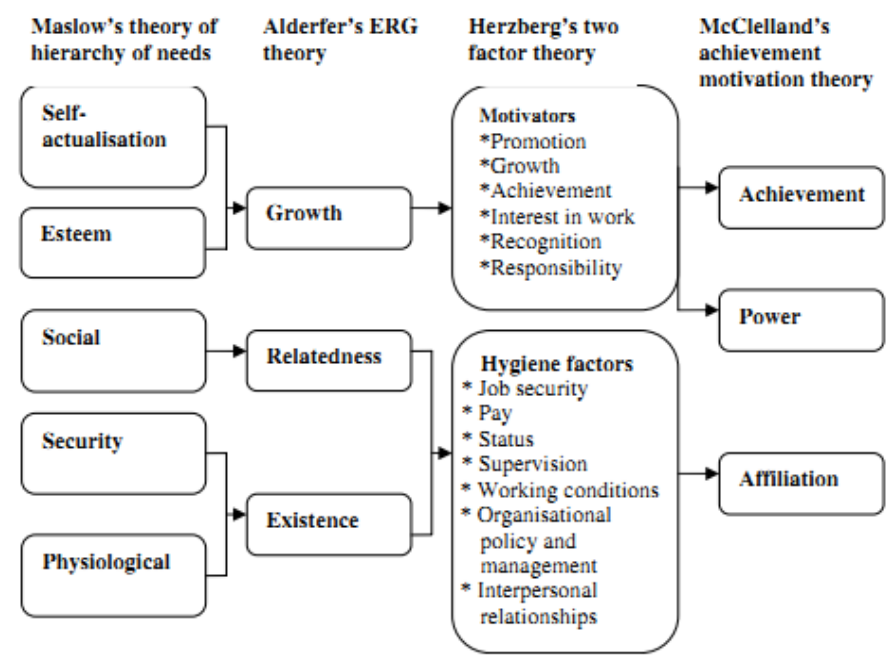

As Maslow (1943) it is clearly understood in the above figure, the most important point of Maslow's hierarchy of needs is that the motivational strength of an unfulfilled higher-level need depends on the fulfilment of a lower-level need. Motivational factors which are given in the figure clearly explains that these issues must be resolved for growth as well as achievement and power.

\section{Affect of Motivation on Teacher/Employee Performance or Behaviour:}

\section{Teacher absenteeism:}

Kadzamira (2003) has observed that there is a link between poor motivation and low level of job satisfaction among teachers and their performance. The performance is reduced because of low morale and as a result teachers makes excuses for themselves to be absent from schools. Nowadays the absenteeism of teachers from school is a serious problem and the reason that you will listen most of the time is that teachers are engaged in secondary employment for example they may be marking exam papers at that time, to meet their expenses because they donot have sufficient income. They are not satisfied with their salaries. In urban areas, teachers can even leave class rooms during lesson time. When teachers are engaged in any other source of income, they donot pay attention to their teaching profession. They are less committed to their jobs, they donot prepare lessons, they donot provide quality education to students. This secondary employement distracts them from teaching.

The Moleni and Ndalama, (2004)study reported that the major reasons for absenteeism are like personal sickness, attending sick family members, attending seminar/workshop, financial 
problems like looking for loans or setting debts, collecting salaries and pensions, residential training and maternity leave.

\section{Professional conduct and performance:}

Poor motivation results in unprofessional behaviours like teacher's misbehavior with students. They may not treat them well like they should be treated. Unprofessional behaviour of teacher has a negative impact on students.

\section{Professional status:}

Teachers are no more valued by society you can say. That profession doesnot commands high status as it was in past teachers were given high status with value. The diminishing status of teaching profession is somehow contributed by low salaries and poor working conditions. Whenever teachers find better salaries and attractive jobs opportunities they shift towards that.

\section{Job Satisfaction:}

The motivated teachers have job related attitude: job satisfaction, if they are motivated they are satisfied with their jobs and if not they will not be satisfied. This dissatisfaction leads to many work related problems like poor performance, absenteeism and turnover.

\section{Teacher deployment:}

The deployment of teachers in less attractive locations is a serious problem because of low teacher motivation. The complexity of deployment of school teachers in less attractive areas is a result of low motivation of teachers. Teaching positions are not being filled in a proper manner in many countries because of many reasons. Rural schools are not attractive for them as compare to schools in urban areas because of the availability of resoures. If we see the qualification profiles of teachers in urban and rural areas, they are pretty much different from each other. In rural areas most teachers are inexperienced which is really stressful and de-motivating. So teachers want to be posted to urban areas for many reasons like quality education for their own children, employment opportunities for spouses, another source of income for their ownself, better living, conditions etc. There is injustice in deployment process where new teachers are forced to teach in rural areas.

\section{Teacher Retention:}

Low motivation leads to poor job satisfaction and as a result high attrition rate of teachers. There are five main types of teacher turnover: departures of teachers at the school level; movements of teachers between public and non-state schools; teacher upgrading; occupational attrition (teachers leaving the profession to take up other jobs); and international 
migration. Teacher retention at the school level is a combination of attrition (through long-term illness and death, resignation, retirement, dismissal) and transfers (lateral, promotion, study leave).

\section{Brain drain:}

Large number of teachers migration from developing countries to developed countries is a result of low teacher motivation. It is argued that "brain drain" of teachers has a negative impact on teacher supply and retention in developing countries.

\section{Job design:}

Rich(1999) emphasized that teacher motivation is really effected by the task itself. Anyone can be de-motivated by boring job, and meanwhile if the job is challenging the teacher enjoys doing that job. The job should be designed in such a way that it looks intresting and challenging. If variety, autonomy and decision authority is added in a job it would be challenging. For adding variety and challenge job enrichment and job rotation should be provided to teachers.

\section{Organizational commitment:}

Porter et al. (1974) defined organizational commitment as "the strength of an individual's identification with and involvement in a particular organization". The teachers who are motivated are committed towards their institutes, they strongly believe in institutes goals and values and they try their level best to achieve these goals. They are willing to exert effort for the success. They have strong desire to be the member of that institute. They donot look for secondary employement. They do their jobs with sincerity because of their commitment.

Meyer and Allen (1991) study indicated that organizational commitment has three dimensions. These are affective, normative and continuance. Strong emotional attachment of employees with their jobs is affective commitment. When employees have sense of duty towards their organizations due to which they want to be the member of that particular organization this is normative commitment and when employees are familier with the costs attached while leaving the organization this is continuance commitment.

Meyer and Allen's (1991) study indicated that there are three dimensions of organizational commitment. So there is a positive relationship between employee commitment due to motivation and organization's success.

\section{Job involvement:}

Lodahl and Kejner (1965) define job involvement as "the degree to which a person's work performance affects his self-esteem". They also argue that motivation results in job involvement and job involvement reduces employee turnover and absenteeism. When a 
teacher is involved in a job and gives importance to a job, he is responsible for quality education. The involved teacher is concerned for institute's progress and for the future of children, the teacher is teaching. Motivation and job involvement are related to each other.

\section{Life satisfaction:}

Heller et al. (2004) explores that motivation has a positive relationship on life satisfaction. It is defined as when a person is motivated towards a job he will be satisfied with his job and as a result he would be satisfied from his life. If he is de-motivated he will not be satisfied with his job and with his life aswell. Quality performance is a result of all these things.

\section{Motivating your students:}

Maehr (1984) stressed that a student successfully complete a task when the teacher pays attention to that student. A learner can only learn when the teacher motivates them, teacher takes interest in student's future, when teacher is concerned with what a student can do, and how to make him do all that. A motivated teacher is a reason of student's motivation. This type of positive behavior of teacher reflects his sense of responsibility towards students. In every possible way the teacher makes his student confident and motivated towards studies and everything else that really matters in life.

\section{Developing Countries:}

Asserts that the quality of students is produced in schools and there performance is being polished by teachers. A motivated teacher teaches better then the demotivated teachers from the limited resources. They founded that the morale and motivation in schools is weak and declining. The relationship of teacher motivation and performance is very strong. The research revealed that the understanding teachers' ability to perform well is neglected." The social context of the teacher, the teacher's attitudes and their working conditions are intimately related in a very complex manner and we need to understand them better... what we do not have is a very clear picture of what motivates teachers, or needed, what demotivates them"(Garrett,1999) .The level of motivation had a great impact on there performance. Performance is a major issue influencing education quality.

In all countries teaching is vocations, which have a intrinsic high level of commitment to the teaching profession. Here are also those who don't want to adopt teaching as a profession, so don't have commitment to job, they do so because they don't have another choice. There motivation and performance will effect the situation. Another issue is remuneration package and poor school management, that is there relationship to management with in and outside school. The third one factor which creates demotivation is the location of school most of the schools were situated in undesirable, disadvantaged locations. The fourth is some secondary and public school lack basic infrastructure, classrooms were old and dusty. Shortage of desk and the windows don't have glass in the window. Most of the under developed countries were affected by HIV/AIDS pandemic. This is open issue in Malawi and Zambia then in PNG, 
although there is also an increasing problem too. It becomes a hurdle for teachers to perform to the best of their ability. It increases the rate of absenteeism and mortality. Other problems were lack of opportunities, training, incentives compensations, house loans, salaries and student behaviors. Similarly the authors divided motivational issues into three major factors.

The first one is organizational and institutational factor which include location of job and job deployment. Some teachers don't follow the proper rule and regulation while training at province level.manny female teachers don't want to work in rural areas because of less incentives provided there in result post became vacant. Improper school infrastructure creates hurdles in teaching, air blowing from window, rain water falling from roof ceilings all of these factors collectively creates lack of motivation and unable the teachers to finish the lessons and teaching programs.

Secondly social and community factor in rural areas, teachers are treated in a respect full manner and people come to them to have solution of there problems but in urban areas teachers lack respect due to changing modes of behaviors and loss of traditional values. Transport, personal and family well being are also effective issues. They don't have access to transport they have to heir local transport due to it the major part of there salary is gone and after that they are unable to fulfill their family expenditures.

The third last is regional and ethnic factor, most of the teachers appointed in rural areas don't know there rural language so they are unable to communicate in meetings with parents and with authorities. (Doctors et al, listening to teachers n.d).Also (Bunnell, 2007) stated that the accountability is a single most factor for low motivation among teachers because most of the teachers are involved in politics and supporter client relations and not as common as in south Asia..Insecurity, lack of safe school building is also an important issue in urban schools. The universal primary education (UPE) also has a great impact on teachers increased number of enrolments, work over load and class size creates demotivation .Salary, and housing and travel are also critical issues affecting teacher morale and motivation. .

Peter et al (2008) stressed that some teachers are so positively motivated that they want to go in other provinces because they know the need of teachers and their values in rural areas. Some of them choose this profession because of strong interest in teaching but some accepted it that they choose to be a teacher because of their parents pressure. A number of teachers who are dissatisfied from their occupation complained a lot of problems about their field. They are affected by both intrinsic and extrinsic factors. The factors causing dissatisfaction are corruption, nepotism, inadequate salary, late arrival of salary, distance from home to school, poor benefit packages, social and economic problems, and behavior of students, work overload and working environment. As discussed in above researches low salary is the single important factor creating demotivation. However corruption, favoritism are two factors of same origin. The recruitment policies are also not working properly. Teacher training issues were not ranked as higher than other but due to economic crisis they also creates demotivation. Another factor raised by male teachers is that their placement and promotion is 


\section{Macrothink}

Journal of Sociological Research

ISSN 1948-5468

2013, Vol. 4, No.2

neglected and preference is given to the female teachers and if they want to move from the post, they have to pay the provincial office education.

Ololube (2004) argues that job satisfaction and motivation are long term streams in growth of education. Every teacher work to fulfill his or her needs. If they are met successfully they are satisfied with their jobs, if not they are dissatisfied. Government argues with teachers that economic conditions are not stable so they are unable to increase their salaries, benefits and improving in working conditions. They also accuse teachers of lethargy, laziness, negligence and lack of enthuthasism. While teacher by their side say that existing structure of salary and working conditions is not better for them to perform effectively. In his study he choose 12 variables out of which he ranked job security and working conditions 1 , pay benefits ranked on number 10, important and influential factors number 12.Dörnyei (2001a:165)explained teaching as a profession whose enthusiasm created from the intrinsic factors states some harmful points which weaken the intrinsic character of the teacher motivation. "Burnout is a professional hazard" (Kottler and Zehn,2000:98).Teacher as a profession is a stressful occupation. There are few factors of feeling burn out. Emotional exhaustion is the first element. It is due to the emotional problems related to families and social society. Another thing is multi tasking many teachers are fed up of double shifts in schools can also cause emotional exhaustion. The next factor is depersonalization, means being distrustful, irritated and serious due to it teachers have negative believes about their contemporaries. The lack of fulfillment of personal needs is the third one de-motivation and disappointed are the symbols of burned-out teachers as they de-motivated with their personal requirements for challenges, acknowledgment and admiration.

\section{Methodology}

In this research qualitative and quantitative methods have been used by the researchers where survey has been conducted in public and private schools. Likert scale is used in quantitative method. Primary data has been collected through questionnaire and interviews. Data was analysed by using t-test in SPSS software. 
Findings and Discussions

Compensation and benefit package

\begin{tabular}{|c|c|c|c|c|c|c|}
\hline \multirow[t]{3}{*}{$\begin{array}{l}\text { Perceived Issues } \\
\text { and challenges } \\
\text { faced by teachers }\end{array}$} & \multicolumn{4}{|c|}{ Types of institutes } & $t$ & $\begin{array}{l}\text { Sig. } \\
\text { tailed })\end{array}$ \\
\hline & \multicolumn{2}{|c|}{$\begin{array}{l}\text { Public } \\
\text { Schools }\end{array}$} & \multicolumn{2}{|c|}{ Private schools } & & \\
\hline & Mean & $\begin{array}{l}\text { Std. } \\
\text { Deviation }\end{array}$ & Mean & $\begin{array}{l}\text { Std. } \\
\text { Deviation }\end{array}$ & & \\
\hline $\begin{array}{l}\text { Compensation and } \\
\text { benefit package }\end{array}$ & 3.33 & .985 & 2.83 & 1.018 & 2.465 & .15 \\
\hline
\end{tabular}

As the results indicate that the mean score for public schools is 3.33 and for private schools is 2.83 and the standard deviation is .985 and 1.018 respectively. The t-score for equality of means that is 2.465 with p-value .15 . The result indicates that public school teachers are somehow agree with their compensation and benefit packages. They get compensation in the form of leaves, medical allowances etc. Public sector employees admit that they get monitory benefits from the government in the form of different packages. Along with regular payment of monthly salaries based on different pay scales they also get medical allowances, leaves with pay, 30 days privilege leaves and casual leaves with pay, medical leaves, children educational allowance, provident funds benefits, benevolent funds and etc. The result indicates that private school teachers disagreed with the statement. They sometimes get these packages which are beneficial for them. Private school teachers get regular monthly salaries but they seldom enjoy the benefits and monitory packages those are offered to the public school teachers. In some special circumstances they occasionally get monitory benefits but only in well reputed schools. These results indicate that there is no significant difference between the two mean scores. Respondents of public school teachers revealed in their interview that they get these benefits on the other side private school teachers are not given such packages. This factor has strong effect on motivation of teachers. If they get these compensation packages they will be highly motivated. Though high monitory packages are offered in public sector schools but due to poor monitoring and inefficient handling the results produced by them are not encouraging. In Private schools though such sort of monitory benefits and packages are seldom offered to the teachers but due the good management and proper handling the teacher performances are found quite outstanding.. 
High quality of service

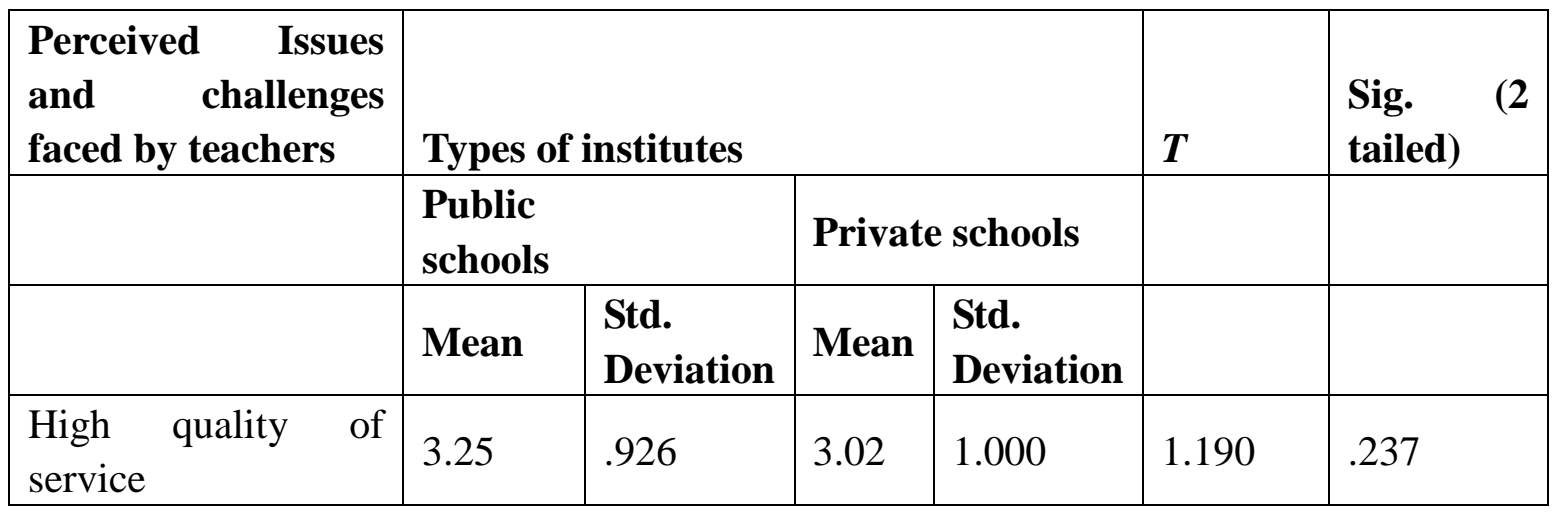

As the results indicate that the mean score for public schools is 3.25 and for private schools is 3.02 and the standard deviation is .926 and 1.000 respectively. The t-score for equality of means that is 1.190 with p-value .237 . The result indicates that teachers of public schools are somehow agreed with this statement that they receive high quality of service when they have a benefit issue or claim. Majority of public school teachers for putting their best efforts to impart quality education to the students but the response from the students were found very poor because of their irregular attending of the class periods. On the other side private school teachers are indifferent with this factor. Their management is supportive if they have such issue. Private school teachers though they are getting less monitory benefits as compare to the public school teachers but they are putting their best efforts to impart quality education in their students. The students are also found corporative and responsive to their teachers. The quality of education found in private schools is much better than the public schools. These results indicate that there no significant difference between the two mean scores. The respondents of both public and private school teachers discussed in their interview that they are motivated by this factor. Because of good management of the schools, teachers' devotion and dedication/commitment, results produced by the private school teachers are much better as compare to the public schools.

Authority to make decisions

\begin{tabular}{|c|c|c|c|c|c|c|}
\hline \multirow[t]{3}{*}{$\begin{array}{l}\text { Perceived Issues } \\
\text { and challenges } \\
\text { faced by teachers }\end{array}$} & \multicolumn{4}{|c|}{ Types of institutes } & \multirow[t]{3}{*}{$t$} & \multirow[t]{2}{*}{$\begin{array}{l}\text { Sig. } \\
\text { tailed })\end{array}$} \\
\hline & \multicolumn{2}{|c|}{$\begin{array}{l}\text { Public } \\
\text { Schools }\end{array}$} & \multicolumn{2}{|c|}{ Private schools } & & \\
\hline & Mean & $\begin{array}{l}\text { Std. } \\
\text { Deviation }\end{array}$ & Mean & $\begin{array}{l}\text { Std. } \\
\text { Deviation }\end{array}$ & & \\
\hline $\begin{array}{l}\text { Decision making } \\
\text { authority }\end{array}$ & 3.29 & .936 & 3.48 & .967 & -1.002 & .319 \\
\hline
\end{tabular}

As the results indicate that the mean score for public schools is 3.29 and for private schools is 
3.48 and the standard deviation is .936 and .967 respectively. The t-score for equality of means that is -1.002 with p-value .319 . The result indicates that teachers of public school are somewhat agree with this factor. In public schools decisions are taken on the already government prescribed rules and regulation. The violation of which is strictly prohibited. The teachers are allowed to exercise their authority on the students only within the already set rules. The changes in the exercise of the authority are allowed only in exceptional cases and that to with the permission of the higher management of the school. The result indicates that private school teachers are agree that they have decision making authority to complete their assigned goals. In private school teachers are often allowed to make decisions of their own for the benefits of the students. They can also exercise the authority but with the consultation of the school management. There is no significant difference between two mean scores. Respondents of both schools revealed in their interview that they can implement their own way of teaching. They can use their own ideas in the classrooms to teach their students. The administration in the well known private schools is found much better than the schools in the public sector. The objectives and goals achievement in private schools is much better as compared the schools of the public sectors.

\section{Work Load}

\begin{tabular}{|c|c|c|c|c|c|c|}
\hline \multirow[t]{3}{*}{$\begin{array}{l}\text { Perceived Issues } \\
\text { and challenges } \\
\text { faced by teachers }\end{array}$} & \multicolumn{4}{|c|}{ Types of institutes } & \multirow[t]{2}{*}{$T$} & \multirow[t]{2}{*}{$\begin{array}{l}\text { Sig. } \\
\text { tailed })\end{array}$} \\
\hline & \multicolumn{2}{|c|}{$\begin{array}{l}\text { Public } \\
\text { Schools } \\
\end{array}$} & \multicolumn{2}{|c|}{ Private schools } & & \\
\hline & Mean & $\begin{array}{l}\text { Std. } \\
\text { Deviation }\end{array}$ & Mean & $\begin{array}{l}\text { Std. } \\
\text { Deviation }\end{array}$ & & \\
\hline Work load & 3.27 & 1.122 & 3.08 & 1.088 & .840 & .403 \\
\hline
\end{tabular}

As the results indicate that the mean score for public schools is 3.27 and for private schools is 3.08 and the standard deviation is 1.122 and 1.088 respectively. The t-score for equality of means that is .840 with p-value .403 . The result indicates that public school teachers agreed with the statement that workload they have to bear. They do not have to work hard to complete their assigned goals. In public sector work load is low or there is no work. If any work is assign to the teachers of the public sector they take it lightly. They check notebooks irresponsible due to which they don't feel workload but it is not in the favor of the students. Students will not come to know about their mistakes and their base will be weak. They have no heavy assignments to do. They don't have to take extra classes in working hours. There is no extra burden of work. The result indicates that private school teachers disagreed with this factor sometimes they have more work to do. In private sectors teachers have so much burden of work. They have to submit their work/assignment on the dead line or before the dead line. Teachers have to become more attentive while checking note books. They have to work hard and efficiently. They have to take numbers of classes some times in their free period teachers have to take fixture or any type of duty will be assign to them. There is no significant 
difference between the two mean scores. the respondents of public school teachers discussed they are assigned less work as Compare to private school teachers. The respondents of private school teachers revealed that they have to teach many classes in their working hours. Sometimes they also bear some extra burden due to that they cannot do their work well. Private school teachers have to answer in front of their principal and have to show all the progress regarding students, their own work etc but public school teachers is not answerable to anyone.

\section{Teacher's dignity}

\begin{tabular}{|l|l|l|l|l|l|l|}
\hline $\begin{array}{l}\text { Perceived Issues } \\
\text { and challenges } \\
\text { faced by teachers }\end{array}$ & \multicolumn{2}{|l|}{ Types of institutes } & & \multicolumn{1}{l|}{$\begin{array}{l}\text { Sig. } \\
\text { tailed) }\end{array}$} \\
\hline & \multicolumn{2}{l|}{$\begin{array}{l}\text { Public } \\
\text { Schools }\end{array}$} & \multicolumn{2}{|l|}{ Private schools } & & \\
\hline & Mean & $\begin{array}{l}\text { Std. } \\
\text { Deviation }\end{array}$ & Mean & $\begin{array}{l}\text { Std. } \\
\text { Deviation }\end{array}$ & & \\
\hline Teacher's dignity & 2.90 & .975 & 3.29 & 1.336 & -1.309 & .194 \\
\hline
\end{tabular}

As the results indicate that the mean score for public schools is 2.90 and for private schools is 3.29 and the standard deviation is .975 and 1.336 respectively. The t-score for equality of means that is -1.309 with p-value .194. The result indicates that the public school teachers not agreed with the changing policies of government. The management doesn't handle these policies properly. Change in policy of the government will be applicable in the public sector whether these policies are in favor if teachers or not. Due to this factor teachers of public sector are less motivated and they don't have high qualified teachers. The result indicates that private school teachers are somewhat agree with this factor. Change in government policies doesn't affect the teacher's dignity of private sector. Private sectors have separate management system which set the policies for teachers separately. Due this teacher's dignity in private sector is satisfied. The result indicates that there is no significant difference between two mean scores. The respondents of public school teachers discussed that the changes in policies are not favorable for them. The respondents of private school teachers discussed that government is not as such involved in their affairs. The changing in policies depends on their management and that's why their teachers' dignity is maintaining and teachers get motivated. 


\section{Resources to do quality work}

\begin{tabular}{|l|l|l|l|l|l|l|}
\hline $\begin{array}{l}\text { Perceived Issues } \\
\text { and challenges } \\
\text { faced by teachers }\end{array}$ & \multicolumn{2}{|l|}{ Types of institutes } & t & $\begin{array}{l}\text { Sig. } \\
\text { tailed) }\end{array}$ \\
\hline & \multicolumn{2}{|l|}{$\begin{array}{l}\text { Public } \\
\text { Schools }\end{array}$} & \multicolumn{2}{|l|}{ Private schools } & \\
\hline & Mean & $\begin{array}{l}\text { Std. } \\
\text { Deviation }\end{array}$ & Mean & $\begin{array}{l}\text { Std. } \\
\text { Deviation }\end{array}$ & & \\
\hline $\begin{array}{l}\text { Resources to do } \\
\text { quality work }\end{array}$ & 3.40 & .774 & 3.42 & .986 & -.073 & .942 \\
\hline
\end{tabular}

As the results indicate that the mean score for public schools is 3.40 and for private schools is 3.42 and the standard deviation is .774 and .986 respectively. The t-score for equality of means that is -.073 with p-value .942 . The results indicate that some respondents of public school teachers don't agree with the resources provided to them. Resources are the basic things to do work in the classrooms when they are missing teachers cannot produce work. In some schools there are lack of chairs, tables, desk, boards in some schools they are not even provided students have to sit on ground or on mates. The mean shows that the respondents are satisfied with the resources provided to them but some of them are neutral towards the resources provided to them because in some activities they are said to share the expense from their salary. Some of the respondents mention that they don't even have a proper building and infrastructure of school. A respondent disclosed in his interview that in private schools school buildings are on rent they are not designed for a school the management tries to modify it according to their requirement which is not effective and create demotivation. The result indicates that there is no significant difference between the two mean scores. Both the public and private school teachers say that they don't have enough resources to work properly even desk, chairs, boards and proper building for the schools is not available to them. The public respondents revealed in there interview that they are asked to teach the students without black boards and improper laboratories due to which they are unable to clear the concept of the students in some practical subjects. The private school teachers are also showing neutral sign towards the factor resources to do the quality work.A private school teacher say that improper rooms and furniture creates demotivation. 


\section{Number of students in class}

\begin{tabular}{|c|c|c|c|c|c|c|}
\hline \multirow[t]{3}{*}{$\begin{array}{l}\text { Perceived Issues } \\
\text { and challenges } \\
\text { faced by teachers }\end{array}$} & \multicolumn{4}{|c|}{ Types of institutes } & \multirow[t]{2}{*}{$t$} & \multirow[t]{2}{*}{$\begin{array}{ll}\text { Sig. } & (2 \\
\text { tailed }) & \end{array}$} \\
\hline & \multicolumn{2}{|c|}{$\begin{array}{l}\text { Public } \\
\text { Schools }\end{array}$} & \multicolumn{2}{|c|}{ Private schools } & & \\
\hline & Mean & $\begin{array}{l}\text { Std. } \\
\text { Deviation }\end{array}$ & Mean & $\begin{array}{l}\text { Std. } \\
\text { Deviation }\end{array}$ & & \\
\hline Students in class & 3.60 & 1.053 & 3.85 & .989 & -1.260 & .211 \\
\hline
\end{tabular}

As the results indicate that the mean score for public schools is 3.60 and for private schools is 3.85 and the standard deviation is 1.053 and .989 respectively. The t-score for equality of means that is -1.260 with $\mathrm{p}$-value .211 . The public schools teachers are agree with the factor that government enrolls sufficient number of students in the class. But some of the respondents say that the management enrolls greater number of students in class room that's why they are unable to handle a large number of populations. They cannot teach the class properly because many of the students take it as a privilege when teacher is unable to keep eye on them. The statistics shows that the most respondents of private school teachers are agree with the statement that management enrolls sufficient number of students in the classroom. However some of them say that in primary classes the number of students is so high which makes teacher uncomfortable to handle the class. Another problem reported by them is some of the schools are running under the trust a teacher cannot punish or talk strictly with the kin of the trustees. The statistics indicates that there is no significant difference between the two means of public and private sector school teachers. The private school respondents said in there interview that due to increase in population the number of students in the class room are also increasing due to which they are unable to handle the class and to produce quality work. Lack of finance doesn't allow the management to avail quality of resources which further causes problems. If comparatively seen the public school teachers are also facing this problem in some schools teachers say that we cannot teach the class without chalks and boards.

\section{Fair treatment}

\begin{tabular}{|c|c|c|c|c|c|c|}
\hline \multirow[t]{3}{*}{$\begin{array}{l}\text { Perceived Issues } \\
\text { and challenges } \\
\text { faced by teachers } \\
\end{array}$} & \multicolumn{4}{|c|}{ Types of institutes } & \multirow[t]{2}{*}{$t$} & \multirow[t]{2}{*}{$\begin{array}{ll}\text { Sig. } & (2 \\
\text { tailed }) & \end{array}$} \\
\hline & \multicolumn{2}{|c|}{$\begin{array}{l}\text { Public } \\
\text { Schools }\end{array}$} & \multicolumn{2}{|c|}{ Private schools } & & \\
\hline & Mean & $\begin{array}{l}\text { Std. } \\
\text { Deviation }\end{array}$ & Mean & $\begin{array}{l}\text { Std. } \\
\text { Deviation }\end{array}$ & & \\
\hline Fairly treated or not & 3.04 & 1.084 & 3.90 & .994 & -4.111 & .000 \\
\hline
\end{tabular}


As the results indicate that the mean score for public schools is 3.04 and for private schools is 3.90 and the standard deviation is 1.084 and .994 respectively. The t-score for equality of means that is -4.111 with p-value .000 . The Statistics indicates that the public school teachers are not satisfied with their treatment in the school by the management and as well as by the students which creates de-motivation to them. According to them only those teachers are awarded who are in relation with management .Some of the respondents claim that the management do not treat them as a teacher. The result indicates that majority of the respondents agreed with the factor that they are fairly treated in the school. Management treats the private school teachers well. In private school the basic infrastructure of the management is missing some times teachers and principal are also working as the management of the school. Some of the respondent shows the neutral behavior towards the fair treatment of them in the school. The statistics indicates that there is significant difference between the two means of public and private school teachers respectively. They collectively reported a problem that they are not treated well due to personal biasness and attitude of management towards specific activity of a teacher. Respondent also mentioned that school are running under the supervision of the trust and the NGO's and the management is also shows concern to them whether they are right or wrong.

\section{Development}

\begin{tabular}{|l|l|l|l|l|l|l|}
\hline $\begin{array}{l}\text { Perceived Issues } \\
\text { and challenges } \\
\text { faced by teachers }\end{array}$ & \multicolumn{2}{|l|}{ Types of institutes } & & \multicolumn{1}{l|}{$\begin{array}{l}\text { Sig. } \\
\text { tailed) }\end{array}$} \\
\hline & \multicolumn{2}{l|}{$\begin{array}{l}\text { Public } \\
\text { Schools }\end{array}$} & \multicolumn{2}{|l|}{ Private schools } & & \\
\hline & Mean & $\begin{array}{l}\text { Std. } \\
\text { Deviation }\end{array}$ & Mean & $\begin{array}{l}\text { Std. } \\
\text { Deviation }\end{array}$ & & \\
\hline Career development & 3.23 & .831 & 3.48 & .922 & -1.417 & .160 \\
\hline
\end{tabular}

As the results indicate that the mean score for public schools is 3.23 and for private schools is 3.48 and the standard deviation is .831 and .922 respectively. The t-score for equality of means that is -1.417 with p-value .160 . The results show that there is lack of opportunities of career development in public sector. They are not satisfied with the career development program offered to them by the government institutes because they consist of a lot of polices which makes the program complicated .Some of the respondents also mention that they have to wait for a long time to be promoted to higher scale of a teacher. Private school teachers shows that few respondents agree towards the factor career development. They are not satisfied with it .Some of them chosen this profession as a last resort they don't have any interest in the current field and some of them are disappointed from the culture of school system that's why they feel de-motivation. The statistics show that there is no significant difference between the two score means. Both the public and private sector school teachers are not satisfied with the development programs provided to them they are complaining lack of opportunities and development packages offered to them and when offered only relatives 
are hired.

Performance Management system

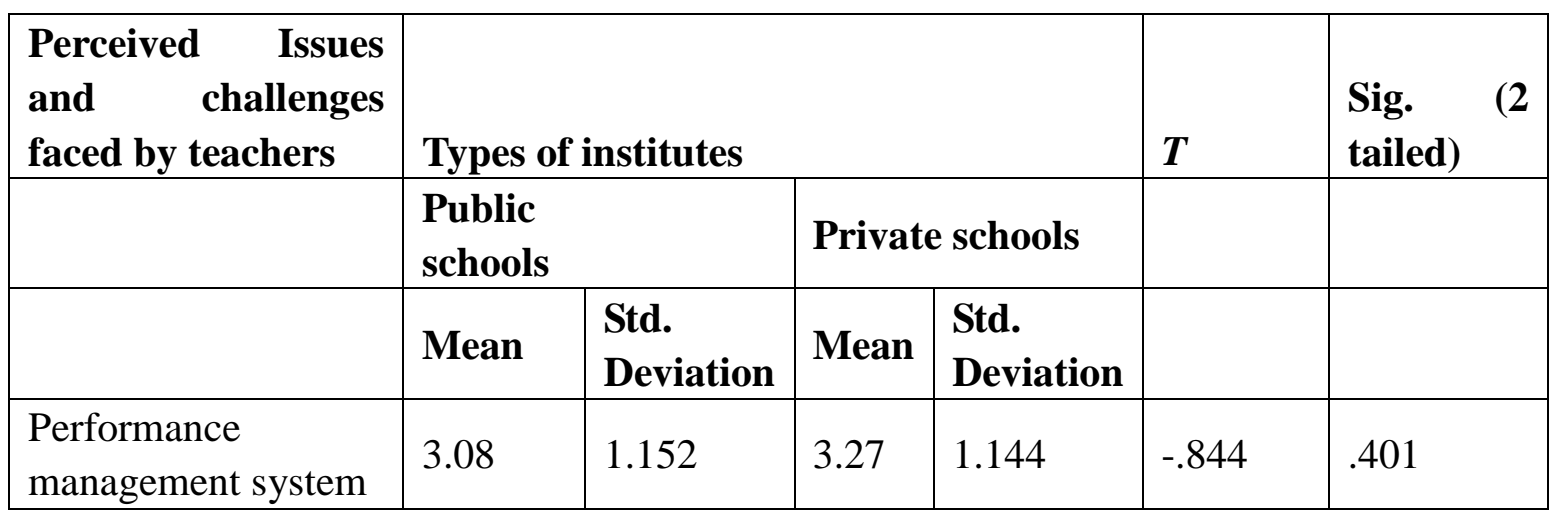

As the results indicate that the mean score for public schools is 3.08 and for private schools is 3.27 and the standard deviation is 1.152 and 1.144 respectively. The t-score for equality of means that is -.844 with p-value .401. The result indicates that public school teachers disagree about this factor. They are not very well aware about their management system because they are only concerned with their own jobs and benefits if provided to them. The performance management standard systems in public sector are of sub-standard type. Majority of schools don't have performance management systems at all. Only in some schools there are some systems but are not very effective. Rewards and perks are given only on the discreasion of the management which makes the teachers less motivated and dissatisfied. The result indicates that they are somewhat agreeing with this factor. Their performance management system is very good. They are fully aware of the management system and their policies. In private sectors of educational system there are specific standards for the performance but in few schools we found no standard for the performance. In well known private schools the rewards, incentives, etc are given on the devotion and performance and no discrimination occur. There are management committees for the annual performance evaluation of the teachers. These committees recommend the increments and rewards for the teachers which motivate them. This result indicates that there is no significant difference between these two mean scores. Public sector is not aware and this causes de motivation among them. But in private sector performance management system is strong due to this teachers are highly motivated but still there is some need for the improvement of the standards set for the performance of the teachers which was discussed with the management. It was also discussed with the public sector school management but without any response and they showed no interest in this regard. 


\section{Recognition and Rewards}

\begin{tabular}{|c|c|c|c|c|c|c|}
\hline \multirow[t]{3}{*}{$\begin{array}{l}\text { Perceived Issues } \\
\text { and challenges } \\
\text { faced by teachers }\end{array}$} & \multicolumn{4}{|c|}{ Types of institutes } & \multirow[t]{3}{*}{$t$} & \multirow[t]{2}{*}{$\begin{array}{ll}\text { Sig. } & (2 \\
\text { tailed }) & \end{array}$} \\
\hline & \multicolumn{2}{|c|}{$\begin{array}{l}\text { Public } \\
\text { Schools }\end{array}$} & \multicolumn{2}{|c|}{ Private schools } & & \\
\hline & Mean & $\begin{array}{l}\text { Std. } \\
\text { Deviation }\end{array}$ & Mean & $\begin{array}{l}\text { Std. } \\
\text { Deviation }\end{array}$ & & \\
\hline $\begin{array}{l}\text { Recognition and } \\
\text { rewards }\end{array}$ & 3.13 & 1.067 & 3.21 & 1.220 & -.322 & .748 \\
\hline
\end{tabular}

As the results indicate that the mean score for public schools is 3.13 and for private schools is 3.21 and the standard deviation is 1.067 and 1.220 respectively. The t-score for equality of means that is -.322 with p-value .748. The result indicates that public school teachers are somehow agreed with recognition and rewards provided to them. Rewards are provided to the teachers on the annual day to appreciate their performances in order to make their work efficiently. Public sector school teachers were found satisfied with their salaries and annual increments. They are much interested in there monitory remunerations and annual increments rather than the imparting the education to the students, the result is that the educational standards in these schools are not improving. The result indicates that private school teachers are satisfied with this factor because these rewards help them in motivating themselves and they produce better results. In private educational institutions the rewards and increments in the teacher salaries are on the performance based. The teachers who impart education properly to the students and show the better performance and results are rewarded handsomely, so they seemed well motivated. Resultantly the educational standards in private schools are improving regularly. These school managements take proper interest and care in rewarding judiciously to the teachers who give good performances. Performance based reward systems in the private educational institution are working successfully and objectively which are resulting in better educational standards. This result indicates that there is no significant difference between these two mean scores. Both the sectors agree with this factor because their management appreciates them on good work and provides them incentives. The performance of reputed private schools seems much better than the public school teachers. Parents of the students try to get their children to be admitted in the reputed private schools then the government schools because of the standard of education in the formers. The growth of private schools especially in the urban areas is increasing in the country day by day. The educational system in the government sponsored schools needs improvement and restructuring. Government has to adopt and introduce modern and revolutionized policies to improve the standards of education in the public sector schools.

\section{Conclusion and Recommendations}

Recommendations for the identified problems are as follows: 


\section{Ml Macrothink}

- Some supervision committies should be set up by the government to supervise and check the irregularties and injustices done to the teachers and take steps to correct all this.

- Through special lectures and trainning the teachers should be made aware to their duties and the responsibilities.

- Positive incentives and rewards should be given to them on imparting quality education.

- The rewards, increments and promotion should be based on the results of performances given by the teachers. The teachers who perform and give better results should be compensated with rewards and other monitory benefits.

- The involvement of the teachers should be ensured to make the crucial and important decision for the school.

\section{References:}

Bedeian, A. G. (1993), Management, 3rd Edition, New York, Dryden Press.

Buford, J. A., Jr. (1990), Extension management in the information age. Journal of Extension, $28(1)$

Kreitner, R. (1995). Management, 6th Edition, Boston, Houghton Mifflin Company.

Herzberg, F., Mausner, B., \& Snyderman, B. (1959). The Motivation to Work (2nd Ed.) John Wiley \& Sons, New York.

Maslow, A. (1970). Motivation and Personality, Harper and Row

Andrabi, T., Das J., Khwaja, A., Vishwanath, T., Zajonc. T., Learning and Educational Achievements in Punjab Schools (LEAPS): Insights to Inform the Policy Debate, (World Bank, 2008).

Thomas K.Crowl, Sally Kaminsky, David M PodeII, 1997, Educational Psychology. The college of Staten Island, City University of New York.

Clifford T. Morgan, 1992-second edition, A brief Introducation to Psychology. The Late professor of psychology.

Robbins, S.P., Coulter, M., Vohra, N. Management (10 ${ }^{\text {th }}$ ed., 345).

Remez Sasson . What Is Motivation and How to Strengthen It. Retrieved on 12, October 2011. http://www.successconsciousness.com/index.htm.

Shameena Silva (2009) Intrinsic Or Extrinsic Motivation - The Most Effective Way To Motivate Employees Retrieved 11, November 2011.

From http://www.articlesbase.com/rss/

G. Jones and J. George . from the book "Contemporary Management."

Report on The System of Education in Pakistan. Nordic Recognition Information Centres

October, 2006

Dawood Shah June 2003 Country Report on Decentralization in the Education System of Pakistan: Policies and Strategies Yes Pakistan.com. Why Pakistan's primary school teachers lack motivation November 10, 2011

Motala, S. 2001. Quality and indicators of quality in South African education: A critical appraisal. International Journal of Educational Development 21(1): 61-78. 
Clifford T.Morgan, 1992-second edition, A brief Introducation to Psychology. The Late professor of psychology.

Khan, T. (2005) Teacher Job Satisfaction and Incentives: A Case Study of Pakistan, Islamabad. Abraham H. Maslow, "A Theory of Human Motivation," Psychology Review, 1943, vol. 50, pp. 370-396.

Maslow, A.H. (1943). A theory of Human Motivation. Psychological Review, 50, p. 370.

Maslow, A.H. (1970). Motivation and Personality. $2^{\text {nd }}$ edition, New York: Harper and Row.

Kadzamira E.C. 2003, Where Has All the Education Gone in Malawi: Employment

Outcomes of Secondary and University Leavers, Brighton: Institute of Development Studies.

Moleni, C. \& L Ndalama, 2004, Teacher Absenteeism and Attrition in Malawian

Primary Schools: A Case Study of Four Districts Draft report.

Rich, C. (1999). Incentive compensation challenges: Attracting and retaining key employees.

The Human Resource Professional, 12(2), 12-15.

Porter LW, Steers RM, Mowday RT, Boulian PV (1974). Organizational commitment, job satisfaction, and turnover among psychiatric technicians. J. Appl. Psychol., 59(5): 603-609.

Meyer JZ, Allen NJ (1991). A three-component conceptualization of organizational commitment. Hum. Resour. Manage. Rev., 1: 61-89.

Lodahl T \& Kejner M (1965). The definition and measurement of job involvement, J. Appl. Psychol., 49: 24-33.

Heller, J., Goulet, L., Mohr, E., (2004), "Mastering motivational theories", [Online] Available from:http://findarticles.com/p/articles/mi_hb3325/is_1_8/ai_n29089793/pg_2/?tag=cont $n t ;$ coll

Maehr, M.L. 1984. Meaning and motivation: toward a theory of personal investment. In: Ames, R.E.; Ames, C., eds. Research on motivation in education: Vol. 1. Student motivation, $p$. 115-44. San Diego, CA, Academic Press.

Hyde, K. Muito, M. and Muito G. (2005) Teacher Motivation and Incentives in Kenya, Nairobi.

Musikanga, M. (2005) Is There A Teacher Motivation Crisis in Zambia?, Lusaka.

Reforming Basic Education in Pakistan, Dr Shahrukh Rafi Khan, SDPI Research and News

Bulletin, Vol. 8, No. 1, Nov 2000-Feb 2001

Statistical Book of Pakistan, 2003-04, Government of Pakistan

Croft, A., 2002, 'Pedagogy in school context: an intercultural study of the quality of learning, teaching and teacher education in lower primary classes in Southern Malawi', unpublished PhD thesis, University of Sussex, UK.

Kadzamira, E.C. \& M. Chibwana, 2000. Gender and Primary Schooling in Malawi, IDS Research Report No 40, Brighton: Institute of Development Studies

Kadzamira, E.C., N. Swainson, D. Maluwa-Banda \& A. Kamlongera, 2001. The

KOTTLER, Jeffrey A. and Stanley J. Zehn. (2000). on being a teacher: The Human Dimension. California: Corwin Press.

Bennell, P., Akyeampong, K. 2007 .teacher motivation in sub-Saharan Africa and south Asia. FID.

Elliot A.J and Dweck C.S.Handbook of competence and motivation (pp.509-526).New York: Guilford Press. 


\section{Macrothink}

Journal of Sociological Research

ISSN 1948-5468

2013, Vol. 4, No.2

Peter and Margaret H, Lalla, J. Ellis, F. 2008. A policy report on the motivation and morale of teachers in Cambodia.

Oloulbe 2008. Teachers job satisfaction and motivation for school effectiveness: An assessment, Finland.

Nadeem, M. , Rana, M. S. , Lone, A.H., Maqabool, S., Naz, K. , Ali, A., 2011. Teachers competencies and factors affecting the performance of teachers in bahawalpur (southern Punjab) Pakistan. International Journal of Business and Social Science. Vol.2 no 19.

Jabeen, N. (2001). Facilitators and Barriers to Career Advancement of Women Civil Servants. Social Sciences and Humanities Journal, 8: No, 1, spring, 2001.

Sarita and Tomer, M. (2004). Teacher Education. Dehli: Isha Books.

Furniss, Elaine (2005). Report of a Needs Assessment of Government Colleges for Elementary Teachers, Punjab Province, Pakistan, 2005. Government of Pakistan-UNICEF Program of Cooperation.

Levy, Jack (2004). Teacher Education Standards and Their Role in Education Reform. Presentation made at the National Teacher Training Conference, Academy for Educational Development.

Shami, Pervez A. (2006). Standards for Education and Standards for Teacher Education. Academy of Educational Planning and Management. Ministry of Education. Islamabad, Pakistan.

Ministry of Education New Zealand (1999). Professional Standards: Criteria for Quality Teaching - Area School Teachers and Unit Holders.

UNESCO and USAID (2005). Donor Support to Education: Lessons Learned Meeting. 23-24 June, 2005. Islamabad, Pakistan.

Warwick, Donald P. and Fernando M. Reimers (1991). Good Schools and Poor Schools in Pakistan. Development Discussion Paper No. 399 ES. HIID.

Jaffar, R. (2005). Teacher Education. Donor Support to Education: Lessons Learned Meeting, 23-24 June, 2005. Islamabad. Final Report.

Khan, Sughra Choudhry (2004). From Practice to Policy: Making a Difference. Report prepared for the Teachers'Resource Centre. Karachi, Pakistan.

Aly, J.H. 2007. Pakistan national education policy. 